Wiraraja Medika : Jurnal Kesehatan
https://www.ejournalwiraraja.com/index.php/FIK
2088-415x (Print) |2685-9998 (online)

\title{
Hubungan Karakteristik Ibu Hamil dengan Sikap terhadap Pelaksanaan Senam Hamil di Puskesmas Srandakan, Bantul
}

\author{
Afi Lutfiyati ${ }^{1 *}$, Dwi Yati ${ }^{2}$, Sujono Riyadi ${ }^{3}$ \\ 1,2,3 Program Studi Keperawatan, Fakultas Kesehatan, Universitas Jenderal Achmad Yani \\ Yogyakarta. \\ 1afi.machsuni@gmail.com* , ${ }^{2}$ dwie.ns215@gmail.com, ${ }^{3}$ sujono_kmpk2005@yahoo.com \\ *Corresponding author
}

\begin{tabular}{ll}
\hline Informasi artikel & ABSTRAK \\
\hline Sejarah artikel: & Senam hamil penting bagi ibu hamil, karena dapat mengurangi \\
Received: & ketidaknyamanan selama kehamilan dan memperlancar proses \\
Revised: & persalinan.Gerakan senam hamil yang paling sederhana dapat dilakukan \\
Accepted: & untuk menjaga kesehatan ibu hamil. Gerakan senam hamil terkandung efek \\
\hline Kata kunci: & relaksasi yang dapat menstabilkan emosional ibu hamil. Pada ibu yang \\
Pengalaman hamil, usia & melaksanakan senam hamil persalinannya akan lebih cepat dibandingkan \\
kehamilan, pekerjaan, & dengan ibu hamil yang tidak melaksanakan senam hamil. Sikap dan praktik \\
sikap, senam hamil. & merupakan komponen penting yang harus dimiliki ibu hamil pada saat \\
& melaksanakan senam hamil. Ada beberapa faktor yang dapat memengaruhi \\
& sikap terhadap pelaksanaan senam hamil diantaranya adalah pengalaman, \\
& media massa, pengaruh kebudayaan, pengaruh orang lain, dan agama. \\
& Penelitian bertujuan mengetahui hubungan pendidikan, usia, pengalaman \\
& hamil, dan pekerjaan ibu hamil dengan sikap terhadap pelaksanaan senam \\
& hamil. Desain penelitian kuantitatif dengan pendekatan cross-sectional \\
& study. Sampel diambil dengan teknik purposive sampling yaitu 36 ibu hamil \\
& yang melaksanakan antenatal care di Puskesmas Srandakan. Instrumen \\
& penelitian adalah kuesioner. Hasil penelitian dianalisis dengan chi-square \\
& test. Penelitian memperlihatkan mayoritas ibu hamil berada pada usia yang \\
& aman 20-35 tahun (94,4\%), Pendidikan ibu mayoritas SMA (77,8\%). Pekerjaan \\
& ibu mayoritas tidak bekerja (80,6\%), dan mayoritas ibu mempunyai \\
pengalaman kehamilan sebelumnya sebanyak 63,9\%. Berdasarkan usia & kehamilan mayoritas berada pada kehamilan trimester tiga sebanyak 66,7\%. \\
& Sedangkan sikap tentang pelaksanaan senam hamil mayoritas mendukung \\
sebanyak $52,8 \%$. Hasil uji chi-square diperoleh nilai p $>0,05$. Tidak terdapat & hubungan pendidikan, usia, pengalaman hamil, usia kehamilan, dan \\
pekerjaan ibu hamil dengan sikap terhadap pelaksanaan senam hamil di & \\
Puskesmas Srandakan.
\end{tabular}

Key word:

Pregnancy experience, gestational age, occupation, attitude, pregnancy exercise.

\section{ABSTRACT}

Pregnancy exercise were important for pregnant mother, it could reduce discomfort during pregnant time and facilitate the delivery process. The simplest pregnancy exercises could be done to provide health status of pregnant mother. The steps of pregnancy exercise contains a relaxing effect that could stabilize emotionally the mother. Pregnant mother who do pregnancy exercises, delivery process were faster than pregnant mother who did not done any pregnancy exercises. Attitudes and practices were important components that pregnant mother must have in carrying out pregnancy exercises. there were several factors that influence the attitude of pregnant mother to pregnancy exercises including experience, mass media, cultural influences, influences of others, and religion. The purpose of the study were to identify the association of education, age, pregnancy experience, and occupation with the attitude of pregnant women to pregnancy exercise. The research were quantitative research design using a cross-sectional study approach. Samples were taken by purposive sampling technique, namely 36 pregnant women who carried out antenatal care at the Srandakan Health Center. A questionnaire were the research instruments. A 
chi-square analysis were used to show the results of the study. The results identified that most pregnant mother were at a safe age of 20-35 years (94.4\%), mother's education was mostly high school (77.8\%). Most mothers were house wife (80.6\%) and most mothers have previous pregnancy experience of $63.9 \%$. Seen from the gestational age, most mothers were in the third trimester of pregnancy as much as $66.7 \%$ and most mothers also had good knowledge as much as $69.4 \%$. While the mother's attitude about pregnancy exercise mostly supports as much as 52.8\%. The $\mathrm{p}$ values obtained $>0.05$ from chi-square test results. There were no association between education, mother's age, pregnancy experience, gestational age, and occupation with the attitude of pregnant mother to pregnancy exercises at Public Health Center in Srandakan district.

\section{PENDAHULUAN}

Salah satu sebab tingginya Angka Kematian Ibu (AKI) adalah adanya penyulit pada saat persalinan (Witjaksono, 2002). Ibu membutuhkan persiapan secara fisik dan mental untuk mempersiapkan persalinan secara aman. Salah satu cara yang dapat dilakukan untuk mendapatkan persalinan secara aman adalah dengan melaksanakan senam hamil. Kegiatan ini dapat dilaksanakan sejak awal kehamilan. Senam hamil yang dilakukan dengan teratur, dapat menjaga kesehatan ibu dan juga kesehatan janin yang dikandungnya (Manuaba, 2010; Maryunani, 2011). Gerakan pada senam hamil yang paling sederhana dapat dilakukan untuk menjaga kesehatan ibu hamil. Gerakan pada senam hamil mamiliki efek yang menenangkan dan dapat menstabilkan emosi ibu yang sedang hamil. Pada ibu hamil yang teratur melaksanakan senam hamil akan lebih kecil kejadian partus lama dibandingkan dengan ibu hamil yang tidak melaksanakan senam hamil. Pada ibu hamil yang melaksanakan senam hamil proses persalinannya akan lebih cepat dibandingkan dengan ibu hamil yang tidak melaksanakan senam hamil (Suratiah et al., 2013). Pelaksanaan senam pada ibu hamil akan berpengaruh pada proses persalinan, dimana seorang ibu hamil yang teratur melaksanakan senam hamil cenderung mengalami proses persalinan lebih cepat sebanyak $27,3 \%$, sebaliknya ibu hamil yang tidak melakukan senam pada saat hamil cenderung akan mengalami persalinan lebih lama yaitu sebanyak 40,9\% (Rahmawati et al., 2016). Sehingga dapat disimpulkan senam hamil sangat penting bagi ibu hamil, sebab dapat mengurangi ketidaknyamanan selama kehamilan dan memperlancar dalam proses persalinan.

Sikap didefinisikan sebagai suatu reaksi maupun respon yang sifatnya masih tertutup pada suatu stimulasi/objek (Azwar, 2011). Sikap adalah merupakan suatu komponen yang penting dan harus dimiliki ibu hamil dalam melaksanakan senam hamil. Di kehidupan nyata, sikap adalah reaksi individu yang bersifat emosional. Sikap menjelaskan adanya kesamaan antara reaksi dan stimulus tertentu. Sikap dan praktik adalah komponen yang penting dan sebaiknya dimiliki seorang ibu hamil yang sedang melaksanakan senam hamil. Ibu hamil membutuhkan informasi mengenai pentingnya senam hamil, terutama kehamilan yang memasuki trimester kedua. Ibu hamil trimester II dan III masih banyak yang belum mengikuti pelaksanaan senam hamil. Kondisi ini mungkin disebabkan karena ibu yang sedang hamil belum mengetahui pentingnya mengikuti kegiatan senam pada saat hamil selama periode kehamilannya (Indriyani dan Suprayitno, 2017)

Ada beberapa faktor yang memengaruhi sikap ibu hamil terhadap senam hamil diantaranya adalah pengetahuan, pengalaman, media massa, pengaruh kebudayaan, pengaruh orang lain, agama, dan media massa (Azwar, 2011). Penelitian Laili (2015) menyebutkan ada hubungan antara usia ibu dengan keikutsertaan ibu yang sedang hamil pada senam hamil $(\mathrm{p}=0,001)$. Penelitian lain yang dilakukan Impartina (2017) menyebutkan ada hubungan antara paritas ibu dengan partisipasi ibu yang sedang hamil dalam melaksanakan senam hamil (nilai $\mathrm{p}=0,001$ ). Oleh karena hal tersebut, maka dibutuhkan penelitian lebih lanjut tentang hubungan karakteristik ibu hamil dengan sikap terhadap senam hamil di Puskesmas Srandakan, Bantul.

\section{METODE PENELITIAN}

Berdasarkan metodenya, penelitian ini termasuk dalam penelitian kuantitatif noneksperimental, menggunakan pendekatan cross-sectional. Kegiatan penelitian ini dilaksanakan di Puskesmas Srandakan Bantul, di ruangan KIA dan ruangan senam 
hamil. Pengambilan data penelitian dilaksanakan pada bulan 27 Juni sampai dengan 25 Juli 2018. Di penelitian ini, populasinya adalah semua ibu yang sedang hamil dan berkunjung di Puskesmas Srandakan Bantul. Jumlah keseluruhan ibu yang sedang hamil yang melaksanakan senam hamil di Puskesmas Srandakan adalah sebanyak 46 orang. Sampel pada penelitian ini merupakan ibu yang sedang hamil dengan usia kehamilan >22 minggu, bersedia menjadi responden, dapat membaca serta menulis, ibu melaksanakan pemeriksaan ANC di Puskesmas Srandakan Bantul tanpa penyakit penyerta. Teknik pengambilan sampel dengan purposive sampling. Proses penentuan besar sampel adalah dengan menggunakan rumus Slovin. Adapun jumlah sampel secara keseluruhan yang diambil sebanyak 36 responden (Nursalam, 2011). Pengumpulan data dilakukan dengan kuesioner. Kuesioner sikap ibu hamil diadopsi dari penelitian Gunawan (2009) yang telah diuji validitas dan reliabilitas sebelumnya. Analisis untuk menguji variabel menggunakan Chi-square test $\left(\mathrm{x}^{2}\right)$ dengan nilai tingkat kemaknaan sebesar $\mathrm{p}<0,05$.

\section{HASIL PENELITIAN}

Tabel 1. Karakteristik ibu hamil di Puskesmas Srandakan $(\mathrm{n}=36)$

\begin{tabular}{lrc}
\hline \multicolumn{1}{c}{ Karakteristik } & jumlah & \% \\
\hline Usia ibu & & \\
Usia berisiko & 2 & 5,6 \\
Usia aman & 34 & 94,4 \\
\hline
\end{tabular}

\begin{tabular}{|c|c|c|}
\hline \multicolumn{3}{|l|}{ Pendidikan } \\
\hline SMA & 28 & 77,8 \\
\hline $\begin{array}{l}\text { Pendidikan } \\
\text { tinggi }\end{array}$ & 8 & 22,2 \\
\hline \multicolumn{3}{|l|}{ Pekerjaan } \\
\hline Tidak bekerja & 29 & 80,6 \\
\hline Bekerja & 7 & 19,4 \\
\hline \multicolumn{3}{|l|}{ Gravida } \\
\hline Primigravida & 13 & 36,1 \\
\hline Multigravida & 23 & 63,9 \\
\hline \multicolumn{3}{|c|}{ Usia kehamilan } \\
\hline Trimester 2 & 12 & 33,3 \\
\hline Trimester 3 & 24 & 66,7 \\
\hline \multicolumn{3}{|l|}{ Sikap } \\
\hline $\begin{array}{l}\text { Tidak } \\
\text { mendukung }\end{array}$ & 17 & 47,2 \\
\hline Mendukung & 19 & 52,8 \\
\hline \multicolumn{3}{|c|}{$\begin{array}{l}\text { Sumber : Data primer diolah tahun } 2018 \\
\text { Tabel } 1 \text {. memperlihatkan bahwa ibu yang } \\
\text { sedang hamil mayoritas kategori usia aman } \\
\text { (20-35 tahun) sebanyak 94,4\%, Pendidikan } \\
\text { sebagian besar SMA sebanyak } 77,8 \% \text {. } \\
\text { Pekerjaan mayoritas pada kategori tidak } \\
\text { bekerja sebanyak } 80,6 \% \text { dan sebagian besar } \\
\text { ibu mempunyai pengalaman kehamilan } \\
\text { sebelumnya sebanyak } 63,9 \% \text {. Sedangkan } \\
\text { pada usia kehamilan mayoritas berada pada } \\
\text { kategori kehamilan trimester tiga sebanyak } \\
66,7 \% \text {. sikap terhadap pelaksanaan senam } \\
\text { hamil sebagian besar mendukung sebanyak } \\
52,8 \% \text {. }\end{array}$} \\
\hline
\end{tabular}

2. Hubungan antara usia ibu, pendidikan, pekerjaan, gravida, dan usia kehamilan dengan sikap terhadap pelaksanaan senam hamil

Tabel 2. Hubungan usia, pendidikan, pekerjaan, gravida, dan usia kehamilan ibu hamil dengan sikap terhadap pelaksanaan senam hamil di Puskesmas Srandakan $(n=36)$

\begin{tabular}{|c|c|c|c|c|c|}
\hline \multirow[t]{3}{*}{ Variabel } & \multicolumn{4}{|c|}{ Sikap terhadap pelaksanaan senam hamil } & \multirow{3}{*}{$\begin{array}{c}p- \\
\text { Value }\end{array}$} \\
\hline & \multicolumn{2}{|c|}{ Tidak mendukung } & \multicolumn{2}{|c|}{ Mendukung } & \\
\hline & $\mathrm{N}$ & $\%$ & $\mathrm{n}$ & $\%$ & \\
\hline Usia ibu & & & & & \\
\hline Berisiko & 1 & 50,0 & 1 & 50,0 & 1,000 \\
\hline Aman & 16 & 47,0 & 18 & 53,0 & \\
\hline Pendidikan & & & & & \\
\hline Cukup & 12 & 42,9 & 16 & 57,1 & 0,434 \\
\hline Tinggi & 5 & 62,5 & 3 & 37,5 & \\
\hline Pekerjaan & & & & & \\
\hline Tidak bekerja & 13 & 44,8 & 16 & 55,2 & 0,684 \\
\hline Bekerja & 4 & 57,1 & 3 & 42,8 & \\
\hline
\end{tabular}




\begin{tabular}{lccccc} 
Gravida & & & & & \\
Primigravida & 8 & 61,5 & 5 & 38,5 & 0,196 \\
Multigravida & 9 & 39,1 & 14 & 60,9 & 0,590 \\
\hline Usia kehamilan & & & & & \\
Trimester 2 & 3 & 25,0 & 9 & 75,0 & \\
Trimester 3 & 14 & 58,3 & 10 & 41,7 & \\
\hline
\end{tabular}

Tabel 2. memperlihatkan ibu pada kategori usia aman (20-35 tahun) mayoritas memberikan sikap mendukung terhadap senam hamil (53,0\%). Ibu dengan pendidikan tinggi sebagian besar memberikan sikap tidak mendukung terhadap senam hamil (62,5\%). Ibu yang bekerja sebagian besar memberikan sikap tidak mendukung terhadap senam hamil $(57,1 \%)$. Ibu yang multigravida sebagian besar memberikan sikap mendukung terhadap senam hamil (60,9\%). Ibu dengan usia kehamilan trimester tiga sebagian besar memberikan sikap tidak mendukung terhadap senam hamil $(58,3 \%)$.

Tabulasi silang berdasarkan Chisquare test dijelaskan pada Tabel 2. memperlihatkan bahwa nilai $p>0,05$. Kesimpulan yang dapat ditemukan bahwasannya tidak ada hubungan antara usia ibu, pendidikan, pekerjaan, gravida, dan usia kehamilan dengan sikap terhadap pelaksanaan senam hamil di Puskesmas Srandakan.

Penelitian ini tidak menemukan adanya hubungan usia ibu dengan sikap terhadap pelaksanaan senam hamil dengan nilai $p$-value $=1,000$. Hal ini disebabkan karena pada ibu dengan usia berisiko $(<20$ atau $>35$ tahun) jumlahnya terlalu sedikit sehingga tidak dapat dibandingkan dengan usia ibu pada kategori aman (20-35 tahun).

Sikap tentang pelaksanaan senam hamil dapat dipengaruhi faktor usia. Usia ibu hamil akan memengaruhi keikutsertaan dalam senam hamil. Semakin dewasa umur ibu, akan semakin matang secara fisik maupun psikologis. Kondisi ini akan memengaruhi tindakan ibu untuk berpartisipasi dalam kegiatan senam hamil secara rutin dan teratur (Yunarsih, 2017).

Usia akan menentukan pengalaman yang didapatkan oleh pribadi seseorang baik itu banyak atau pun sedikit. Sikap dapat dibentuk oleh pengalaman pribadi dan faktor emosional (Stuart \& Laraia (2011).
Penelitian ini memperlihatkan bahwa mayoritas responden berada pada kategori usia aman (20-35 tahun) sebanyak 94,4\%. Usia adalah lama waktu hidup sejak dilahirkan. Apabila seorang individu mempunyai kematangan usia yang cukup, maka diharapkan akan mempunyai pola berpikir dan pengalaman berpikir yang lebih matang. Tahap usia perkembangan seseorang akan banyak dipengaruhi oleh kemampuan kognitif dan kemampuan perilakunya (Potter \& Perry, 2005).

Faktor lain yang memengaruhi sikap ibu hamil tentang senam hamil adalah pendidikan ibu. Pendidikan ibu sebagian besar SMA $(77,8 \%)$. Pendidikan pada tingkat level yang rendah dapat menghambat perkembangan sikap seseorang dalam hal penerimaan beberapa informasi dan bermacam-macam nilai yang baru saja diperkenalkan (Mubarak \& Chayatna, 2009). Lembaga pendidikan seperti sekolah dapat menjadi faktor yang memengaruhi adanya perubahan sikap. Sistem di dalam lembaga pendidikan dapat memiliki pengaruh pada pembentukan sikap karena lembaga tersebut mampu memberikan dasar pada pengertian dan konsep moral di dalam pribadi seseorang (Azwar, 2011).

Hasil penelitian ini tidak menemukan adanya hubungan pendidikan ibu dengan sikap terhadap pelaksanaan senam hamil $\mathrm{p}=0,434$. Hal ini disebabkan karena pada ibu yang berpendidikan tinggi lebih sedikit jumlahnya sehingga tidak dapat dibandingkan dengan ibu yang berpendidikan cukup.

Pendidikan formal akan memengaruhi pengetahuan dan perilakunya. Secara formal, seorang individu dengan pendidikan yang lebih tinggi diharapkan memiliki pengetahuan yang jauh lebih baik dibandingkan dengan seorang individu dengan pendidikan yang lebih rendah. Individu tersebut akan lebih mampu dan mudah memahami pentingnya kesehatan dan bagaimana dapat memanfaatkan 
pelayanan kesehatan tersebut (Mubarak, 2010).

Pada level tingkat pendidikan individu semakin tinggi, maka individu tersebut akan semakin mudah dalam menerima datangnya informasi. Pada kondisi ini akan semakin banyak juga pengetahuan yang akan dimiliki. Demikian pula sebaliknya, level pendidikan yang kurang baik dapat menghambat perkembangan sikap individu terhadap nilai-nilai yang baru dikenal. Semakin tinggi level pendidikan ibu hamil, maka wawasan berpikirnya juga akan semakin baik, sehingga akan memengaruhi pula terhadap pola pikir dan tindakan ibu untuk berperan serta dalam pelaksanaan senam hamil (Yunarsih, 2017).

Faktor status pekerjaan juga berpengaruh terhadap sikap. Menurut Wawan dan Dewi (2010), menyebutkan bahwa individu yang bekerja akan memiliki informasi dan pengalaman yang banyak. Segala sesuatu yang pernah dialami individu tersebut dapat turut serta membentuk bahkan memengaruhi penghayatan individu terhadap respon pada pengaruh sosial yang dapat menjadi salah satu hal yang mendasari terbentuknya sikap. Pesan yang dibawa oleh informasi dan sifatnya mendukung, jika cukup kuat, akan mampu memberikan dasar secara afektif pada penilaian terhadap sesuatu hal sampai akhirnya mampu membentuk arah pada sikap tertentu (Azwar, 2011). Hasil penelitian ini menunjukkan sebagian besar responden tidak bekerja $(80,6 \%)$ namun memiliki sikap yang mendukung tentang senam hamil dikarekan pernah mendapatkan penyuluhan tentang senam hamil dari Puskesmas.

Berdasarkan uji statistik didapatkan $p$-value $=0,684$, hasil ini menunjukkan tidak adanya hubungan pekerjaan ibu dengan sikap terhadap pelaksanaan senam hamil. Hal ini disebabkan karena pada ibu yang bekerja lebih sedikit jumlahnya sehingga tidak dapat dibandingkan dengan ibu yang tidak bekerja. Menurut Markum (1991) dalam Nursalam (2010), bekerja merupakan kegiatan yang menyita waktu. Ibu hamil yang memiliki pekerjaan mempunyai kecenderungan menggunakan mayoritas waktunya untuk bekerja di luar rumah. Kondisi ini menyebabkan partisipasi ibu pada pelaksaanaan senam hamil menjadi rendah, bahkan sampai tidak mengikuti sama sekali. Ibu hamil yang seorang pekerja akan merasakan lelah dan capek setelah bekerja seharian di luar rumah. Kondisi ini menyebabkan ibu hamil akan cenderung lebih memilih untuk berisitirahat saja.

Pengalaman persalinan yang banyak akan menentukan sedikit atau banyaknya partisipasi ibu pada pelaksanaan senam hamil (Impartina, 2017). Pengalaman seorang individu dapat menjadi salah satu faktor yang dapat memengaruhi perilaku. Perilaku seseorang dapat terbentuk sesuai dengan pengalaman yang dimilikinya. Pengalaman ibu dapat memotivasi seorang ibu hamil untuk berpartisipasi pada pelaksanaan senam hamil. Pada akhirnya seorang ibu yang sedang hamil akan menyadari bahwasannya pelaksanaan senam pada saat sedang hamil dapat membantu lancarnya proses persalinan berdasarkan pengalaman ibu tersebut (Wahayu, 2013).

Pelaksanaan senam hamil dapat dimulai pada saat usia kehamilan 22 minggu. Pada saat usia tersebut kondisi ibu sudah siap dan kuat untuk melaksanakan kegiatan senam hamil (Yunarsih, 2017). Responden penelitian ini usia kehamilan paling muda adalah 24 minggu pada saat mulai melaksanakan senam hamil. Pada usia kehamilan tersebut kandungan ibu sudah cukup kuat untuk melaksanakan senam hamil dengan risiko keguguran yang minimal. Ibu hamil sudah mengetahui dan memahami tentang pelaksanaan senam hamil karena adaya informasi yang diberikan oleh petugas Puskesmas.

Hasil penelitian ini juga tidak mendapatkan adanya hubungan antara pengalaman hamil/gravida ibu dengan sikap terhadap pelaksanaan senam hamil dengan $p$-value $=0,196$. Hal ini disebabkan karena pada ibu primigravida lebih sedikit jumlahnya sehingga tidak dapat dibandingkan dengan ibu multigravida.

Hasil penelitian menunjukkan mayoritas ibu memiliki kategori pada sikap mendukung tentang pelaksanaan senam hamil yaitu sebanyak 19 responden $(58,2 \%)$. Hasil ini sesuai dengan penelitian Elizawarda (2016) yang memperlihatkan bahwa dari 36 responden mayoritas memiliki sikap positif (75\%). Sikap individu merupakan suatu respon atau pun reaksi yang sifatnya masih tertutup terhadap sebuah stimulus atau pun objek (Azwar, 
2011). Sikap memperlihatkan ada atau tidaknya kesamaan antara reaksi dan stimulus tertentu dalam kehidupan nyata yang membuat reaksi dapat bersifat emosional. Seorang ibu yang sedang hamil pada saat melaksanakan senam hamil harus memiliki sikap yang positif karena merupakan suatu komponen penting yang harus dimiliki.

\section{Simpulan}

Berdasarkan pembahasan maka kesimpulan yang dapat diambil pada penelitian ini adalah: Mayoritas ibu hamil berada pada kategori usia yang aman (20-35 tahun). Pendidikan ibu sebagian besar SMA. Pekerjaan ibu mayoritas pada kategori tidak bekerja, dan sebagian besar ibu mempunya pengalaman kehamilan sebelumnya. Berdasarkan usia kehamilan ibu mayoritas berada pada kategori kehamilan trimester tiga. Sedangkan sikap ibu terhadap pelaksanaan senam hamil sebagian besar mendukung. Tidak ada hubungan antara usia ibu, pendidikan ibu, pekerjaan ibu, pengalaman hamil, dan usia kehamilan dengan sikap terhadap pelaksanaan senam hamil di Puskesmas Srandakan.

\section{DAFTAR PUSTAKA}

Azwar, S, 2011. Sikap Manusia Teori dan Pengukurannya. Yogyakarta: Pustaka Pelajar.

Elizawarda, 2016. Hubungan Pengetahuan dengan Sikap Ibu Hamil terhadap Senam Hamil di Desa Sei Litur Tasik Kecamatan Sawit Seberang Kabupaten Langkat, PANNMED, 11(1): 23-32.

Gunawan R., 2009. Hubungan antara Pengetahuan Ibu Hamil dengan Sikap Ibu tentang Senam Hamil di Rumah Sakit PKU Muhammadiyah Yogyakarta. Skripsi. Universitas Muhammadiyah Yogyakarta.

Indriyani, R., \& Suprayitno, E. (2017). Hubungan Postpartum Blues Dengan Keputusan Menggunakan KB Pasca Nifas Di UPT Puskesmas Lenteng. Journal Of Health Science (Jurnal Ilmu Kesehatan), 2(2), 70-75. https://doi.org/https://doi.org/10.24 929/jik.v2i2.552

Impartina, A, 2017. Hubungan Paritas dengan Partisipasi Ibu Hamil Mengikuti Senam Hamil. SURYA. 09(02): 44-48.
Laili U., 2015. Analisis Faktor-Faktor yang Memengaruhi Keikutsertaan Senam Hamil pada Ibu Hamil di BPS Nina Surabaya. Jurnal Ilmiah Kesehatan. 8(2):171-174.

Manuaba, IBG. 2010. Ilmu Kebidanan Penyakit Kandungan dan KB, Jakarta: EGC.

Maryunani A., 2011. Senam Hamil, Senam Nifas, dan Terapi Musik, Trnas Info Media, Jakarta. Hal: 48.

Mubarak W.I., Chayatina, N, 2009. Ilmu Kesehatan Masyarakat Teori dan Aplikasih. Jakarta: Salemba Medika.

Mubarak, 2010. Promosi Kesehatan. Yogyakarta: Graha Ilmu.

Nursalam, 2010. Metodologi Penelitian Keperawatan Pendekatan Paritas (edisi 3). Jakarta: Salemba Madika. , 2011. Konsep dan Penerapan Metodologi Penelitian Ilmu Keperawatan, Jakarta: Salemba Madika.

Potter, P.A, \& Perry, 2005. A.G, Buku Ajar Fundamental Keperawatan: Konsep, Proses dan Praktik. Edisi 4.Vol 2. Alih Bahasa: Renata Komalasari, dkk. Jakarta: EGC.

Rahmawati NA, Sutaryono, Lestari S., 2016. Hubungan Senam Hamil terhadap Lamanya Proses Persalinan pada Ibu Bersalin di Wilayah Kerja Puskesmas Bayat Klaten. Jurnal Involusi Kebidanan. 6(11): 30-37.

Stuart, G. W \& Laraia, M. T. 2011. Prinsip dan Praktik Keperawatan Psikiatrik. Jakarta: EGC.

Suratiah, Hartati N., Yuniati NW, 2013. Pengetahuan Ibu Hamil tentang Senam Hamil. Jurusan Keperawatan Polteknik Kesehatan Denpasar Bali. Tersedia di http://poltekkesdenpasar.ac.id/files/JURNAL\%20GEM A\%20KEPERAWATAN/JUNI\%202014/S uratiah,\%20dkk.pdf diakses 31 Agustus 2020.

Wahayu, S, 2013. Hubungan Keikutsertaan Senam Hamil dengan Kemajuan Persalinan Kala 1 Fase Aktif di Wilayah Kerja Puskesmas Cukir Kab. Jombang.

www.stikespemkabjombang.ac.id/eju rnal/index.php/Januari2014/article/ download/69/115+\&cd=12\&hl=id\&ct $=\ln k \& g \mathrm{l}=\mathrm{id}$.

Wawan, A \& Dewi, M. 2013. Teori dan Pengukuran Pengetahuan, Sikap dan 
Perilaku Manusia. Yogyakarta: Nuha Medika. Witjaksono, A, 2002. Persalinan Tanpa Nyeri dengan Anestesi Epidural Ditinjau dari Kedokteran dan Islam. http://www.tabloid-nakita.com.

Yunarsih, N, 2017. Hubungan Karakteristik dan Dukungan Keluarga dengan Perilaku Senam Hamil pada Ibu Hamil di Wilayah Banten Girang Kota Serang. Faletehan Health Journal. 4(2): 194200. 